\title{
Urinary insulin levels in health and disease-a concise review
}

\author{
FREDERICO AUN \\ M.D. \\ Michael M. Meguid \\ M.B., B.S. \\ J. Stuart Soeldner \\ M.D. \\ Noedir A. G. Stolf \\ M.D.
Department of Surgery and Medicine, Harvard Medical School at the Peter Bent Brigham Hospital, Boston, Massachusetts, U.S.A. and the Department of Surgery, University of Sao Paulo Medical School, Sao Paulo, Brazil

\begin{abstract}
Summary
The kidneys are the most important extrahepatic site of insulin breakdown and play a significant role in regulating the systemic insulin level in normal subjects. In man, a renal arteriovenous insulin concentration difference of about $30 \%$ has been measured, and since 'insulin clearance' values are less than the glomerular filtration rates, insulin is probably removed from blood by a combination of filtration and tubular secretion. In normal subjects a constant fraction of circulating insulin is removed by the kidney. This fraction is independent of the arterial concentration but varies with creatinine clearance. Of the amount filtered, most is completely resorbed and degraded by the cells of the proximal convoluted tubules. These cells have a high insulinase content and recent evidence would point to the possible existence of a renal tubular transport mechanism for insulin. The amount of insulin excreted in the urine is small and does not exceed $2 \%$ of the filtered load. In diabetics the insulin requirements often decrease with progressive renal failure. Derangements in carbohydrate metabolism have been noted in patients with renal failure while insulin clearance' is elevated in uraemia, chronic and acute renal failure. In nephrotic syndrome there is no change in renal insulin excretion. In severe trauma, 'insulin clearance' is elevated in patients with normal renal function despite a relative hypoinsulinaemia for the prevailing degree of glycaemia.
\end{abstract}

\section{Introduction}

The development of accurate techniques for the measurement of insulin opened the field for the investigation of insulin levels in various body fluids.

The existence of a hypoglycaemic agent in urine which was believed to be insulin was suggested by Best and Scott in 1923. The chemical and biological properties of this agent were extensively studied by

Correspondence: Dr Michael M. Meguid, Department of Surgery, Peter Bent Brigham Hospital, Boston, Massachusetts 02115 .
Fisher and Noble (1923), Lawrence, Madders and Millar (1930), and Uberrack and Zell (1931). From these biological experiments it was reasonably concluded that after glucose loading insulin or an insulin derivative was excreted in the urine. Furthermore, Partos (1929) and Lawrence et al. (1930) did not find blood sugar lowering substance in the urine of diabetics and fasted animals, while Recordier and Andrac (1935) and Goadby and Richardson (1940) demonstrated that the exclusion of the kidneys from the circulation in rabbits led to a persistence ob insulin action in blood. It was inferred that the organs were partly responsible for the elimination. of insulin from the blood, thereby implying the removal of insulin via urine. In 1948, using a biological assay technique, Mirsky et al. (1948), quantitatively measured insulin in pooled concentrated urine of normal subjects. Yalow and Berson (1959) described an insulin specific radioimmunoassay technique for the measurement of insulin in serum which proved to be a more precise method. Using an immunoassay method, Jørgensen (1966) measured and confirmed the presence of insulin in the urine of non-diabetic and diabetic subjects with a high degree of reliability, while Rubenstein, Lowry and Fraser (1967a) used a double-antibody insulin assay to measure insulin under basal conditions and following a stimulus to endogenous insulin secretion. They found that insulin excretion per hour correlated well with the mean serum insulin level and that insulin clearance' appeared not to vary with changes in serum insulin concentrations but varied directly with creatinine clearance. Urinary insulin levels, as measured over an extended period of time, reflected average serum insulin levels (Jørgensen, 1966; Rubenstein et al., 1967b; Jørgensen, 1969b; McArthur and Stimmler, 1966; Rubenstein and Spitz, 1968), thereby providing a useful clinical tool in the study of the factors influencing insulin regulatory mechanisms in carbohydrate metabolism.

Immunoassay procedures used for measuring 
insulin in urine are essentially the same as for serum, differing only in the preparation of the urine samples. In our laboratory, we have found the following method reliable: urine samples are preserved at $-20^{\circ} \mathrm{C}$ before assay. The $\mathrm{pH}$ of the thawed urine sample is adjusted to $8.0( \pm 0.1)$ by the addition of $0 \cdot 1 \mathrm{~N} \mathrm{NaOH}$ or $\mathrm{HCl}$. The volume of base or acid is usually too small to require the correction of a dilution factor. Five per cent bovine serum albuminborate buffer is added to dilute the urine sample (1:4) to assure negligible protein-ionic strength effect. This solution is then assayed for insulin using an immunoassay method such as the doubleantibody technique previously described by Soeldner and Slone (1965).

\section{Renal handling of insulin: in vivo and in vitro observations}

The arteriovenous insulin difference varies between 30 and $55 \%$ in anaesthetized dogs following an insulin infusion (Zaharko, Beck and Blankenbaker, 1966; McCormick et al., 1969). In fasting man, Chamberlain and Stimmler (1967), measuring endogenous venous insulin levels, noted a $30 \%$ arteriovenous difference. Considering the renal insulin extraction ratio (A-V/A) and a normal renal plasma flow of $650 \mathrm{ml} / \mathrm{min}$, the renal 'insulin clearance'* was calculated to be $200 \mathrm{ml} / \mathrm{min}$. In dogs, McCormick et al. (1969) also found the renal clearance of insulin to exceed the glomerular filtration rate.

There is increasing evidence that insulin as well as other proteins are filtered by the glomerulus and removed from the tubular fluid as it flows along the nephron (Cortney, Sawin and Weiss, 1970; Narahara et al., 1958). Hardwicke and Squire (1955) noted that the filtration of proteins into the urine is inversely proportional to their molecular weight, while tracer studies using labelled insulin (mol. wt 6000) in rats (Narahara et al., 1958), mice (Beck and Fedynskyj, 1967) and rabbits (Corvilain et al., 1971) show a progressive and increasing concentration of the iodine isotope in the glomeruli, proximal tubular lumina and in the cells of the tubules (Narahara et al., 1958; Bourdeau, Chen and Carone, 1973; Darmady, 1965). Recently, Cortney et al. (1970), studying the absorption mechanism of protein in renal tubules, found that the absorption of insulin along the proximal tubule was $30-50 \%$ of the injected load. Since the percentage absorbed was constant when the concentration of insulin was varied, it suggests the existence of a renal tubular transport maximum for insulin. Smaller amounts of insulin were also absorbed when injections were made in distal con-

* The term clearance is used in the context of:

$$
\frac{U \mu U / \mathrm{ml} \times \mathrm{V} \mathrm{ml} / \mathrm{min}}{\mathrm{P} \mu U / \mathrm{ml}}
$$

voluted tubules. The kidney thus removes a significant amount of renal artery insulin, the majority of which is freely filtered by the glomerulus while the remainder is excreted by the peritubular capillaries into the lumen of the proximal convoluted tubules from which $98 \%$ is resorbed into the tubular cells, less than $2 \%$ of the filtered load appearing in the urine. Zaharko et al. (1966) demonstrated that occluding the ureter, which stops glomerular filtration, decreased the renal clearance of insulin by about $50 \%$.

The high insulinase content in the proximal tubular cells, described by Mirsky et al. (1949), and the diminished amounts of insulin in the renal vein, has led to the conclusion that insulin is degraded by the tubules. Thus the kidney is regarded as a major extrahepatic site for insulin catabolism (Rubenstein and Spitz, 1968; Allgood, 1961).

In animal experiments and in human subjects a constant fraction of circulating insulin is removed by the kidney which is independent of the arterial levels. The amount of insulin in the urine increases in a constant proportion to a corresponding increase in arterial insulin levels (Jørgensen, 1969a; McCormick et al., 1969; Chamberlain and Stimmler, 1967; Darmady, 1965). A physiological variation in the urinary insulin output during a 24-hr period corre? lates with the circadian variation of insulin produc tion (Gagliardino, 1968).

Insulin excretion is related to body size and creatinine clearance. Urinary insulin may be expressed as $\mu U / \mathrm{mg}$ of creatinine or $\mu U / \mathrm{kg}$ of body $\mathrm{wt} / \mathrm{hr}$. The 24-hr urinary output in adults is about 14,000 $\mu U$ (Jørgensen, 1966; Jørgensen, 1969a), although mean levels ranging from $160,000 \mu \mathrm{u} / 24 \mathrm{hr}$ to $5400 \mu U / 24 \mathrm{hr}$ have been reported in different series of normal individuals by Rubenstein et al. (1967b) and Najjar and Stephan (1970). Urinary exretion rises during a glucose tolerance test to levels around $800 \mu U / \mathrm{hr}$ (Spitz et al., 1970). Some consideration should be given to the importance of measuring renal insulin clearance during steady state glucose and insulin levels. If measurements are made during the transient conditions of rising glucose and insulin levels during a GTT, falsely low clearance values are found. Rabkin and Colwell (1969) found an equilibration period of $20-30 \mathrm{~min}$ was required to obtain meaningful results. The insulin output in urine is low in the healthy newborn on the first day of life but increases by six-fold on the fifth day with the mean urinary levels rising to $20 \mu \mathrm{U} / \mathrm{hr}$ (Lowry and Schiff, 1968). However, since body weight is not a good index of metabolic mass, because of the variable body-water content of the neonate, the correlation between urinary insulin and body weight is not simple. On the other hand, in children between the ages of 8 and 16 years, despite widely varying 
24-hr excretions ranging between 2500 and $17,500 \mu U$, a correlation between urinary insulin and body weight was found by Jørgensen (1969a), although some authors could only demonstrate it in children weighing $40 \mathrm{~kg}$ or less (Najjar and Stephan, 1970).

In the third trimester of a normal pregnancy, Trayner et al. (1967) were able to show that, in spite of the raised fasting serum levels which were three times higher than the normal fasting values, the renal clearance of insulin is diminished to a mean value of $0.18 \mathrm{ml} / \mathrm{min}$ during an oral glucose tolerance test. These findings were thought to be due to alterations in renal circulation or in renal tubular function occurring during pregnancy. This abnormality could also be attributed to anti-insulin effects of placental lactogen.

\section{Renal handling of insulin: pathological conditions}

As early as 1886 , Stokvis noted that following the development of nephropathy there was an improvement in the clinical condition of diabetic patients (Gagliardino, 1968). In 1951, Zubrod, Eversole and Dana (1951), in a review of 190 cases from Johns Hopkins Hospital, found that the onset of the Kimmelstiel-Wilson syndrome was accompanied by a decrease in insulin requirements. The insulin excretion in urine is found to be lowered in non-obese adult diabetics without impairment of the renal function and the mean daily output is in the range of $8800 \mu U$ (Jørgensen, 1966; Jørgensen, 1969). In obese diabetics urinary insulin is somewhat lower than in normal subjects, although this is not statistically significant. This is not the case in siblings of childhood-onset diabetics, who tend to excrete high amounts of insulin in urine (McArthur and Stimmler, 1966). Insulin $\alpha$ chain, which is produced by the action of glutathione-insulin transhydrogenase on insulin, is normally eliminated in urine in quantities five times greater than insulin. The 24-hr urinary elimination of this protein is also higher in diabetics (Varandani, 1970).

In obesity the urinary insulin levels are greatly increased $(30,300 \mu U / 24 \mathrm{hr})$, but levels fall steadily during starvation and rise again upon eating (Jørgensen, 1969a; Hellier, 1970; Lowy et al., 1966).

Several authors have reported abnormal carbohydrate metabolism in patients with renal failure (Briggs et al., 1967; Cerletty and Engbring, 1967; Friis and Hindberg, 1969; Horton, Johnson, and Lebowitz, 1968; Lowrie et al., 1969; Lowrie et al., 1970), suggesting that insulin antagonism, relatively decreased insulin secretion and impaired insulin degradation are contributory factors to abnormal carbohydrate metabolism in the uraemic state (Spitz et al., 1970). Rabkin et al. (1970) provided direct evidence that renal insulin uptake virtually ceases in diabetic subjects with a glomerular filtra- tion rate under $20 \mathrm{ml} / \mathrm{min}$. Serum has little if any insulin deactivation properties. The rate of dis- $\frac{\varrho}{c}$ appearance of labelled insulin from plasma is delayed $\stackrel{.}{\Rightarrow}$ in uraemic patients (O'Brien and Sharp, 1967; Silvers et al., 1969) and does not significantly differ from the disappearance rates seen in anephric patients (Corvilain et al., 1971). This suggests that the degradation of insulin is mainly dependent on functioning renal tissue (Rubenstein and Spitz, 1968). In patients with chronic renal failure and uraemia the urinary loss of insulin is markedly increased, reaching mean values above $1000 \mu U / \mathrm{hr}$ (Spitz et al., 1970; Rubenstein et al., 1967a; Lowy et al., 1971). In acute renal failure (Chamberlain and Stimmler, 1967), or during its recovery, the urinary insulin clearance is elevated. The same occurs in patients with Fanconi syndrome or cadmium nephropathy in which the disease affects almost exclusively the renal tubules. On the other hand, nephrotic syndrome, a predominantly 'glomerular' disease, causes little or no disturbance in the renal excretion of insulin (Lowy et al., 1971).

In a case of islet cell adenoma of the pancreas, the urinary insulin loss was found to be increased, but after the surgical removal of the tumour, the $24 \mathrm{hr}$ output returned to normal levels (Willner and Weinstein, 1950).

The excretion of insulin by the kidneys 48 he following trauma was examined by Meguid, Aur and Soeldner (1975). Six severe trauma patients and five matched control subjects were studied. Blood and urine samples for insulin and glucose were obtained at $2 \mathrm{hr}$ intervals during a control period and during the infusion of $5 \%$ glucose in water at $100 \mathrm{ml} / \mathrm{hr}$ for $6 \mathrm{hr}$. The mean baseline serum insulin levels in trauma patients were significantly higher than the mean serum insulin value in control subjects. In the trauma patients, it rose throughout the glucose infusion reaching a value which differed significantly from the mean serum insulin in the normal subjects. However, when the serum insulinplasma glucose ratio was calculated, a 'relative' hypoinsulinaemia was found, the injured subjects being 'pseudodiabetic' (Meguid et al., 1974). The total urine insulin and the urine insulin concentrations were significantly higher in the injured patients before and during the glucose infusion. The insulin clearance in the trauma patients was significantly greater than in control subjects. No significant difference was found in the urea nitrogen and creatinine clearance between the two groups, their renal function being the same.

Wide and Thoren (1972) investigating renal excretion of insulin and other polypeptides for 4-5 days following surgery found these to be increased when compared to preoperative measurements. These observations were attributed to a decrease in 
tubular resorption, although arteriovenous differences were not measured.

On the basis of the reviewed data, it would appear that renal tubules exhibit the physiological property of a transport maximum for insulin. An increase in insulin levels in urine is found when circulating insulin concentrations exceed this threshold or when tubular function, and hence insulin degradation, is impaired.

The knowledge gained from the determination of insulin in urine has contributed to our understanding of carbohydrate metabolism. The non-invasive sampling procedures together with the direct relationship between mean urinary and serum levels of insulin are some of the advantages of its use in routine studies, especially in infants and small children.

However, the major contributions derived from urinary insulin studies include: (1) a more precise understanding of the physiology of insulin handling by the kidney; (2) a suggestion that insulin has an effect on renal metabolism; (3) an explanation for the sudden decrease in insulin requirements in diabetics who develop renal failure; (4) its potential use in the estimation of free insulin levels in patients with insulin antibodies in plasma; (5) its use as a sensitive marker for proximal tubular disorders.

\section{References}

Allgood, J.W. (1961) The renal clearance of I-131 during the infusion of NaI-131 and insulin-I-131. Diabetes, 10, 7.

BECK, L.V. \& FEDYNSKYJ, N. (1967) Evidence from combined immunoassay and radioautography procedures that intact insulin ${ }^{125} \mathrm{I}$ molecules are concentrated by mouse kidney proximal tubule cells. Endocrinology, 81, 475.

BeST, C.H. \& SCOTT, D.A. (1923) Insulin in tissues other than the pancreas. Journal of the American Medical Association, 81, 382.

Bourdeau, J.E., Chen, E.R.Y. \& Carone, F.A. (1973) Insulin uptake in the renal proximal tubule. American Journal of Physiology, 225, 1399.

Briggs, J.D., BuchanaN, K.D., Luke, R.G. \& MCKiddie, M.T. (1967) Role of insulin in glucose intolerance in uraemia. Lancet, i, 462.

Cerletty, J.M. \& Engbring, N.H. (1967) Azotemia and glucose intolerance. Annals of Internal Medicine, 66, 1097.

Chamberlain, M.J. \& Stimmler, L. (1967) The renal handling of insulin. Journal of Clinical Investigation, 46, 911.

Cortney, M.A., SAwin, L.L. \& WeisS, D.D. (1970) Renal tubular protein absorption in the rat. Journal of Clinical Investigation, 49, 1.

Corvilain, J., Brauman, H., Delcroix, C., Toussaint, C., VEREERS-TRAETEN, P. \& FRANKSON, J.R.M. (1971) Labeled insulin catabolism in chronic renal failure and in the anephric state. Diabetes, 20, 467.

DARMADY, E.M. (1965) Correlation of renal function and structure. Journal of Clinical Pathology, 18, 493.

FISHER, N.F. \& NoBLE, B.E. (1923) Excretion of insulin by the kidneys. American Journal of Physiology, 67, 72.

FrIIS, T. \& HindBerG, I. (1969) Blood levels of insulin in uraemic patients. Acta medica scandinavica, 186, 323.

GagliardiNo, J.J. (1968) Physiological variations of insulin output in urine. Metabolism, 17, 139.
GoADBY, H.K. \& RiCHARDSON, J.S. (1940) On the disappearance from the blood of intravenously injected insulin. Journal of Physiology, 97, 417.

HARDWICKE, J. \& SQUIRE, J.R. (1955) The relationship between plasma albumin concentration and protein excretion in patients with proteinuria. Clinical Science, 14, 509.

Hellier, M.D. (1970) The effects of prolonged starvation and refeeding on 24-hour urinary insulin levels in obese subjects. Journal of Endocrinology, 47, 73.

Horton, E.S., JohnSON, C. \& Lebowitz, H.E. (1968) Carbohydrate metabolism in uremia. Annals of Internal Medicine, 68, 63.

JøRGENSEN, K.R. (1966) Immunoassay of insulin in human urine. Acta endocrinologica, 51, 400.

JøRGENSEN, K.R. (1969a) Evaluation of the double anti-body radioimmunoassay of insulin and the determination of insulin in plasma and urine in normal subjects. Acta endocrinologica, 60, 327.

JøRGENSEN, K.R. (1969b) Radioimmunoassay of insulin in plasma and urine in obese subjects and in diabetic patients. Acta endocrinologica, 60, 719.

LaWrence, R.D., Madders, K. \& Millar, H.R. (1930) The excretion of insulin in urine. British Journal of Experimental Pathology, 11, 117.

Lowrie, E.G., Soeldner, J.S., HAMPers, C.L. \& Merrill, J.P. (1969) Uremic carbohydrate-insulin metabolism. Journal of Clinical Investigation, 48, 53a.

Lowrie, E.G., Soeldner, J.S., HAmpers, C.L. \& Merrill, J.P. (1970) Glucose metabolism and insulin secretion in uremic, prediabetic, and normal subjects. Journal of Laboratory and Clinical Medicine, 76, 603.

Lowy, C. \& SCHIFF, D. (1968) Urinary excretion of insulin ip the healthy newborn. Lancet, i, 225.

Lowy, C., Rubenstein, A.H., Wright, A.D., Martin, T.Jê\& FRASER, T.R. (1966) Urinary immunochemical insulin in normal, obese, and obese diabetic subjects during oral glucose test and starvation. Diabetologia, 2, 209.

Lowy, C., Wright, A.D., Fraser, T.R., Rubenstein, A.H. \& SPITZ, I. (1971) Urine excretion of insulin and growth hormone in subjects with renal failure. Acta endocrinologica, $67,85$.

MCARThur, R.G. \& Stimmler, L. (1966) Urinary insulin excretion in healthy children and in siblings of childhoodonset diabetics. Lancet, ii, 1236.

McCormick, J.R., Sonksen, P., Soeldner, J.S. \& Egdahl, R.H. (1969) Renal handling of insulin and growth hormone in hemorrhagic shock. Surgery, 66, 175.

Meguid, M.M., Brennan, M.F., Aoki, T.T., Muller, W.A., BALl, M.R. \& MoORE, F.D. (1974) Hormone-substrate interrelationship following trauma. Archives of Surgery, 109, 776.

Meguid, M.M., Aun, F. \& Soeldner, J. (1975) Increase in urine insulin excretion in trauma. Surgical Forum, 25, 273.

Mirsky, I.A., Podore, C.J., WaChman, J., Broh-Khan, R.H. \& BUCHER, S. (1948) The urinary excretion of insulin by normal and diabetic subjects. Journal of Clinical Investigation, 27, 515.

Mirsky, I.A., Brok-Khan, R.H., Perisutti, G. \& Brand, J. (1949) The inactivation of insulin by tissue extracts. I. The distribution and properties of insulin inactivating extracts (insulinase). Archives of Biochemistry, 20, 1.

NaJjar, S.S. \& STEPhan, L. (1970) Urinary insulin. II. Excretion in children and adults. Metabolism, 19, 301.

Narahara, H.T., Everett, N.B., Simmons, B.S. \& Williams, R.H. (1958) Metabolism of insulin-I ${ }^{131}$ and glucagon-I ${ }^{131}$ in the kidney of the rat. American Journal of Physiology, 192, 227. 
O'Brien, J.P. \& Sharpe, A.R., JR (1967) The influence of renal disease on the insulin $I^{131}$ disappearance curve in man. Metabolism, 16, 76.

Partos, A. (1929) Regulation des Kohlehydratstoffwechsels. Ausscheidung des Insulins durch die Nieren und ihre Bedingungen. Pflügers für die Gesamte Physiologie des Menschen und der Tiere, 22, 562.

RABKIN, R. \& Colwell, J.A. (1969) The renal uptake and excretion of insulin in the dog. Journal of Laboratory and Clinical Medicine, 73, 893.

Rabkin, R., Simon, N.M., Steiner, S. \& Colwell, J.A. (1970) Effect of renal disease on renal uptake and excretion of insulin in man. New England Journal of Medicine, 282, 182.

RECORdier, M. \& ANDRAC, M. (1935) Recherches sur la réaction de l'animal à l'insuline avant et après néphrectomie. Marseille Médical, 17, 741.

Rubenstein, A.H., Lowy, C. \& Fraser, T.R. (1967a) Radioimmunoassay of insulin in urine. Diabetologia, 3, 453.

Rubenstein, A.H., Lowy, C., Welborn, T.A. \& Fraser, T.R. (1967b) Urine insulin in normal subjects. Metabolism, 16, 234.

Rubenstein, A.H. \& SpITz, I. (1968) Role of the kidney in insulin metabolism and excretion. Diabetes, 17, 161.

Silvers, A., Swenson, R.S., Farquhar, J.W., Reave, G.M. \& Hess, R.E. (1969) Derivation of a three compartment model describing disappearance of plasma insulin $\mathrm{I}^{131}$ in man. Journal of Clinical Investigation, 48, 1461.

SoeldNeR, J.S. \& SLONE, D.S. (1965) Critical variables in the radioimmunoassay of serum insulin using the double antibody technique. Diabetes, 14, 771 .
Spitz, I.M., Rubenstein, A.H., Bersohn, I., Wright, A.D.

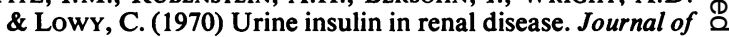
Laboratory and Clinical Medicine, 75, 998.

Trayner, I.M., Welborn, T.A., Rubenstein, A.H. \& $\overrightarrow{\overline{\bar{F}}}$ Fraser, T.R. (1967) Serum and urine insulin in late $\mathscr{G}$ pregnancy and in a few pregnant latent diabetics. Journal of Endocrinology, 37, 443.

UberRACK, K. \& ZeLL, F. (1931) Ueber das Vorkommen von Insulin in Harm. Biochemisches Zentralblatt, 239, 42.

VARANDANI, P.T. (1970) Urinary excretion of insulin A chain by normal and diabetic patients. Diabetes, 19, 98 .

WIDE, L. \& THOREN, L. (1972) Increased urinary clearance $\vec{\circ}$ for albumin, B2-microglobulin, insulin and luteinizing hormone following surgical or accidental trauma. Scandinavian Journal of Clinical and Laboratory Investigation, 30, 275.

WiLlNer, V. \& WeInSTEIn, V.A. (1950) Islet cell adenoma of the pancreas with increased insulin excretion in the urine. New York State Journal of Medicine, 50, 1103.

Yalow, R.S. \& Berson, S.A. (1959) Assay of plasma insulin in human subjects by immunological methods. Nature, 184, 1648.

Zaharko, D.S., BeCK, L.V. \& BlankenbakeR, R. (1966) Role of the kidney in the disposal of radioiodinated and non-radioiodinated insulin in dogs. Diabetes, 15, 680.

Zubrod, C.G., Eversole, S.L. \& Dana, G.W. (1951) $\backsim$ Amelioration of diabetes and striking rarity of acidosis in $\mathbb{D}$ patients with Kimmelstiel-Wilson lesions. New England Journal of Medicine, 245, 518. 